\title{
The Lingering Face of Gender Inequality in Latin America
}

\author{
María Magdalena Camou and Silvana Maubrigades
}

\section{Introduction}

The composition of the labour market in most Latin American countries has changed greatly in the last four decades with a huge increase in the proportion of women in the urban labour market (Camou 2012). Female labour force participation began to increase in the 1970s and this continued through the 1980s and 1990s. In Argentina, Brazil, Uruguay, Mexico and Chile the female participation rate of around $20 \%$ in 1960 increased to $40-50 \%$ in 2000.

The demographic, technological and economic factors behind this process are discussed in the literature. Although this change opens new opportunities for women to become more economically independent, a high proportion are still inactive, and increased women's participation has not eliminated segregation in the labour market.

Recent studies show that the Latin American countries are heterogeneous in this respect. The predominant trend in the 1980-1990s was increased inequality, although this began to reverse in the twenty-first century (Bourguignon et al. 2004; Bértola and Ocampo 2012). However, the gender component of inequality change has not been sufficiently incorporated into these results.

Our main aim in this study is to reconstruct the gender wage gap for a sample of Latin American countries to frame explanations of its evolution and impact on inequality. Our data come from the Censuses and Household Surveys in each country.

Our research involves an exhaustive analysis of wage differences between men and women and focuses on how the gender gap has changed over time and its relation to inequality in the different countries. Our sample consists of Argentina, Bolivia, Brazil, Chile, Colombia, Costa Rica, Ecuador, El Salvador, Guatemala, Honduras, Mexico, Nicaragua, Paraguay, Peru, Uruguay and Venezuela.

M.M. Camou $(\bowtie) \bullet$ S. Maubrigades

Universidad de la República, Uruguay 
Our emphasis is on reconstructing gender indicators for the long run, insofar as this is possible with the sources available, and we analyze the different trajectories and patterns of inequality that are specifically related to gender, and check them against global income distribution trends.

Our hypothesis is that the evolution of the gender wage gap is an important component of overall inequality and it has nonlinear effects. Although this gap has narrowed in recent decades, it is still wide, especially in the Latin American countries where inequality is high and where the incorporation of women into the labour force has lagged behind.

In the next section, we summarize the theoretical links between the increasing female labour supply and inequality, and set the most important results from Latin American research on the subject and the goals of the chapter. Section "The Current Situation" presents our methodology and the sources used. Section "Data and Methodology" discusses the latest data documenting the evolution of female labour force participation and education in twentieth-century Latin America. It also explores the relation between the levels of women's participation in the labour market and their education. In section "The Evolution of Female Labour Force Participation and Education Achievement During the Twentieth Century" we examine the evolution of the gender wage gap and inequality indicators. Section "Measuring Inequality and the Gender Wage Gap" estimates the impact of female labour supply, overall inequality and education on the gender gap. The last section draws some conclusions.

\section{Theoretical Approach}

Latin America has always had high levels of inequality, and today, in spite of recent improvements, it is still the second most unequal region in the world, just below sub-Saharan Africa.

Latin American studies agree that the main cause of increasing inequality in the region has been the process whereby political power, wealth and income have become concentrated in the hands of landowning and capitalist elites and of the people who control work and trade relations (Bértola and Ocampo 2012).

In the First Globalization period inequality in Latin America increased, and while the gap was not as wide as in other regions at that time like Africa and Asia it was still too great to enable these Hispanic countries to catch up with the developed world.

In the industrialization period (1930-1980), Latin American social development indicators had higher growth rates than at any other time in the region's history, although the improvement was more marked in some countries than others.

There was also an improvement in equity levels in the countries that managed to develop welfare state systems such as Argentina, Chile and Uruguay. However, other countries had high levels of inequality either because there were big differences in the composition of the population (indigenous people, peasants, descendants of 
slaves) or because their labour markets were strongly segmented with gaps between formal and informal workers that highlighted the differences in state regulation.

Starting in the 1970 s, the levels of equity that had been attained previously began to diminish. This was due to the drastic deregulation of labour markets, increasing segmentation in job markets, a widening gap between the skilled and the unskilled workforce, along with an industrialization slowdown, less state participation and a cutback on policies to redistribute wealth.

Many authors consider that the persistence of inequality is related to social, cultural and economic frameworks and the fact that discrimination and prejudice are embedded in formal and informal institutions. This particularly affects gender inequality, which according to the literature (Sarasúa and Gálvez 2003) is related to false beliefs and stereotypes that permeate education, family and functioning of the labour market.

Since 1970, women in Latin America have had considerably higher levels of well-being, measured in terms of health and education, than women in other developing regions. However, in spite of this progress, Latin American women have not had equal opportunities to earn income and have largely been excluded from positions of power in political and economic institutions. This makes the region an interesting context in which to consider the effects of globalization, both because the moves toward liberalization have been substantial and because women have had many of the prerequisites to participate in the market economy.

There is considerable discussion in the literature about the consequences of increasing women's participation in the labour force during the globalization period, and interpretations of the evidence are diverse. According to the neoclassical view, as exemplified by the Stolper-Samuelson model, in developing countries free trade leads to rising wages for unskilled work, which is the relatively abundant factor in these economies (Samuelson 1948). Since unskilled work is often done by women we can infer from the Stolper-Samuelson model that globalization leads to increased demand for women to work, and hence should have as a final consequence a relative expansion of female participation and a narrowing of the gender gap (see the case of Mexico in Dell 2005; Artecona and Cunningham 2002; Garcia Cuellar 2001).

However, the evidence for the period 1970-1990 does not support this theory insofar as the growth of demand for female labour has not produced any robust decline in the gender earnings gap, which varies greatly between different regions of the world (Çağatay and Ertürk 2004). Moreover, the narrowing of gender gaps cannot be attributed only to the globalization process because other changes also had an impact. It may be that the improved quality of female labour with the incorporation of workers who were more experienced and better educated (O'Neill and Polachek 1993, Goldin 2000) and the fall in wages for less skilled male workers (Blau and Kahn 1997) came into play, rather than just an increase in the demand for female labour.

The most common heterodox approach to this question has been to consider the effect of gender wage gaps on successful export-led growth. Given that women are excluded from certain occupations and sectors, trade opening brought with it an increase in the labour supply of women in certain kinds of work, and this raised unemployment rates and reduced wages (Bergmann 1974) or perpetuated wage gaps (Joekes 1999; Seguino 2000; Berik et al. 2003). 
Another approach in the literature has focused on the sacrifices that globalization has forced women in developing countries to make (Beneria 2003; Beneria et al. 2000). With very small or in some cases no improvements in household technologies, greater female participation levels in paid occupations have meant more total hours of work for women than for men. Adjustment policies and public expenditure cutbacks in the same period have had negative effects on welfare, health and other human capital services. This affects women more than men, since the former are usually responsible for the human capital formation of their children. Therefore changes in women's economic situations must be analyzed together with other human and social capital conditions that determine their final market power.

\section{The Current Situation}

Research on the evolution of the gender gap in the globalization era in Latin America has been addressed in various ways but there is scant literature with a historical perspective. One reason for this is that the data is very difficult to obtain. Prior to 1970 and before the first Household Surveys there is little aggregate statistical evidence relating to the gender wage gap.

Reyes Campo (2012) has studied the evolution of the gender wage gap in Chile using new sources of pre-1960 data. Prior to her work, there was no data for wages by gender for Chile. She has been able to document the gender gap from 1939 to 1974, using social security data. Although the gender wage gap diminished over time, the ratio of women's wages to male wages only increased 14 percentage points from 1939 to 1968. So the evidence points towards discrimination.

For Uruguay, Camou (2010) studied the evolution of the gender gap in the textile and meatpacking industries, based on business archives for the period of 19151957. Her research also shows a trend towards a shrinking gender wage gap in these industries of about $20 \%$. Another paper compares the forces responsible for the evolution of gender gap and wage inequality in South Asia, East Asia and Latin America (Camps et al. 2006). Human capital, health improvement, labour market liberalization and equal treatment enforcement laws seem to be the main exogenous variables affecting women's economic situation. Between 1975 and 2000 the gender gap narrowed, the main exception to the rule is China, where the economic gap between men and women increased. Everywhere else, the erosion in the gender gap has resulted in a fall of wage dispersion. In short, the narrowing of the gender gap during the second global era has tended to reduce wage inequality measured by both the Gini and Theil indexes.

Hoyos and Nopo (2010) focus on the changes in the 1990s and 2000s and analyze Household Survey data for 1992 and 2007, controlling by education, number of children and other characteristics of the population. Their research explores the impact of changing characteristics of the labour supply on gender earnings inequality. The research shows that the gender gap decreased by $7 \%$ overall during the 
period but with great heterogeneity among countries, and that cohort effects linked to life cycle influence gender earnings.

For the same two decades, Gálvez (2001) examined the dynamic of women joining the labour market and concluded that, despite improvements in the female activity rate, education level and the gender gap, their situation continued to be worse than men's on indicators like the unemployment rate, the activity rate and the persistence of the wage gap. Greater gender equality is reduced less to economic aspects and more to institutional, cultural or regulatory aspects. Mexico and Chile are good examples of this negative correlation as they have the lowest levels of women's income related to higher GDP per capita. Considering the impact of these changes on inequality, Gálvez remarks that the increase in inequality among women, which was due to uneven education gains, may have contributed to an increase in overall inequality.

Our research adds to this literature by extending the period under study thus to capture the impact of previous gender inequality on the present gender gap. Our purpose is to learn more about path dependency. Are the countries with an early high level of gender discrimination those in which it is more difficult to bring women into the workforce?

Lastly, we look at the relationship between overall inequality and gender inequality. We examine whether gender inequality and total inequality share the same trends, whether and why they can have an opposite trend.

\section{Data and Methodology}

Our research concentrates on the differences between women and men in paid work. We do not take into account women who do unpaid work, although this was the biggest group in the female population in the period. It is clear that although gender inequality cannot be reduced merely to a comparison between the sexes, the first step in the analysis must be to focus on a statistical breakdown by gender.

International comparisons are still constrained by the lack of reliable data. Part of the work that women do in poor countries is in the informal economy and at home and/or for piece rates. The information documenting this kind of work is scarce and is often not comparable across countries. Thus, we focus on market earnings only. Income inequality is higher than earnings inequality because wage earnings are less disperse than property and self-employment incomes.

Data on wage earnings disaggregated by gender come from Household Surveys ${ }^{1}$ in each country, and we use it to calculate the wage per hour for each sex. In most of the datasets we exploit, the unit of observation is the household, and this gives us Gini coefficients for income and expenditure (Deininger and Squire 1996, 1998; World Bank 1995; Higgins and Williamson 2002). Other approaches have focused on individuals instead of households, using national account information (see

\footnotetext{
${ }^{1}$ Household Surveys include individual and household information.
} 
Bourguignon and Morrison 2002; Sala-i-Martin 2003). Since our unit of analysis has to be the individual and not the household, Gini coefficients for household income hide important information about the unequal economic position of women in the household.

We calculate the Gini index for earnings inequality in the economy as a whole, and for inequality among men and among women. We supplement this measure with calculations of the so-called generalized entropy measures, the best known of which are the Theil indexes. These indexes enable us to estimate how much overall inequality is explained by inequality within groups and how much by inequality between groups. We use these indexes to disaggregate inequality into its gender sources.

\section{The Evolution of Female Labour Force Participation and Education Achievement During the Twentieth Century}

There is a line of research that documents female labour force participation in the long run. Important studies have been done by Goldin $(1994,2006)$ for the USA, and she finds a "U" relation between female employment rates and economic growth. This is due to the relation between education and economic development. At low levels of development, education increases more for men than for women. As income rises, women's participation decreases. When income increases further, education resources expand and women receive more education, which promotes their participation in the labour market. With more education and the expansion of non-industrial employment, women's participation continues to increase and thus forms the "U" (Psacharopoulos and Tzannatos 1989; Schultz 1990). This evolution has been explored for countries with different income levels. The results show that those with higher or lower levels of income have higher female labour force participation rates than middle-income countries (Pampel and Tanaka 1986; Psacharopoulos and Tzannatos 1989; Tzannatos 1999).

Documentation of the evolution of female labour force participation in Latin America is very recent (Camou and Maubrigades 2013). Researchers have to struggle with the fact that, in general, women workers have not been well documented. The censuses carried out in the first decades of the twentieth century are inconsistent in the way they register women's participation in the primary sector. This makes the total primary sector employment change atypical because work there tends to be less formalized and many women are involved in productive as well as home care activities.

There is another problem with the first censuses in Argentina, Chile and Uruguay carried out at the end of the nineteenth century and the early years of the twentieth century. These record each individual's occupations regardless of whether or not that person was employed at the time. The present-day concept of "unemployed" 
was less applicable when wage labour was the exception rather than the rule. However, this was a period of rapid economic growth which implies that unemployment was probably very low.

Three periods can be distinguished:

1. 1910-1940: a fall in female labour participation in some countries like Argentina and Chile

2. 1940-1970: few changes in the Latin American countries studied

3. 1970 to the present: explosive growth in female labour participation rates

The data collected for the years 1930-1970 give quantitative support to the thesis that female participation in labour markets decreased during the import substitution period. The state promoted a sort of male-breadwinner model during this period in Uruguay and Chile, which fostered a decrease in women's participation in the labour market (Todaro 2004; Espino and Azar 2007).

Female labour force participation began to increase moderately in the 1970s and this trend continued into the 1980s (Table 1). However, only in the 1990s did the region see a significant improvement, in general, and it still remained lower than in the developed countries (Camou and Maubrigades 2013).

Besides this, the trajectories of female activity rates diverged across Latin America. Chile, Uruguay and Argentina had a relatively high rate of female labour participation from the beginning of the period, while Brazil, Colombia and Mexico were much further behind. By the end of the period, Brazil and Colombia had caught up with the first three. The other countries considered in Table 1 have much lower participation rates and, despite some improvement, they have never reached the levels of the Latin leaders.

Although the long-term trend was upwards throughout Latin America, the evidence shows no single pattern in how these countries incorporated women into the labour market during their various stages of development.

As regards education, over the last 60 years the educational level of Latin American countries has progressed to an unprecedented degree. In 1950, the illiteracy rate was about $40 \%$ among persons aged 15 and over; by 2005 it had fallen below $10 \%$. The speed of progress has varied between countries and the illiteracy rate remains high in some countries, in particular those with large indigenous populations.

In the second half of twentieth century, in most of Latin America, female years of schooling increased to near or even slightly higher than men in countries like Argentina, Brazil, Costa Rica and Uruguay. Moreover, gender schooling differences have been reduced especially in recent decades. Only in countries with high illiteracy rates and/or large indigenous communities like Guatemala, Nicaragua or Honduras do we still see big gender gap in schooling.

Considering the expansion of primary education coverage followed by continual growth in basic education, Latin America has presented a set of education policies geared specifically to less privileged groups (in terms of ethnicity, geographical location and socioeconomic status). However, gender inequalities persist in a group of countries but are hidden behind overall averages. 


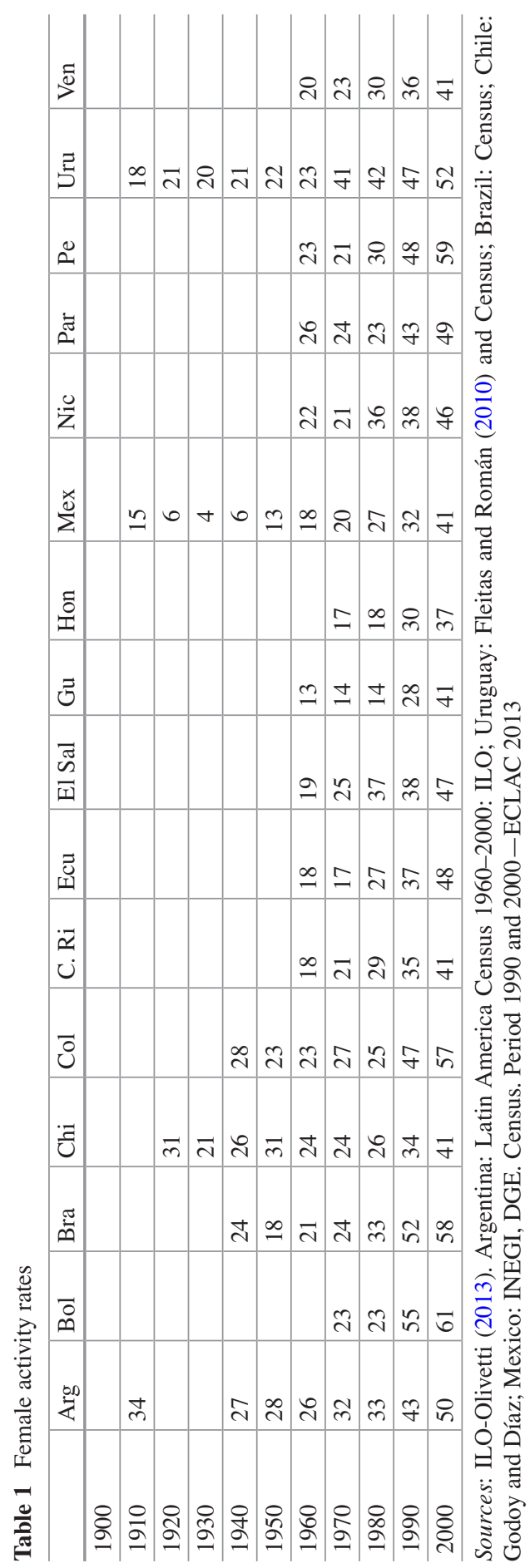




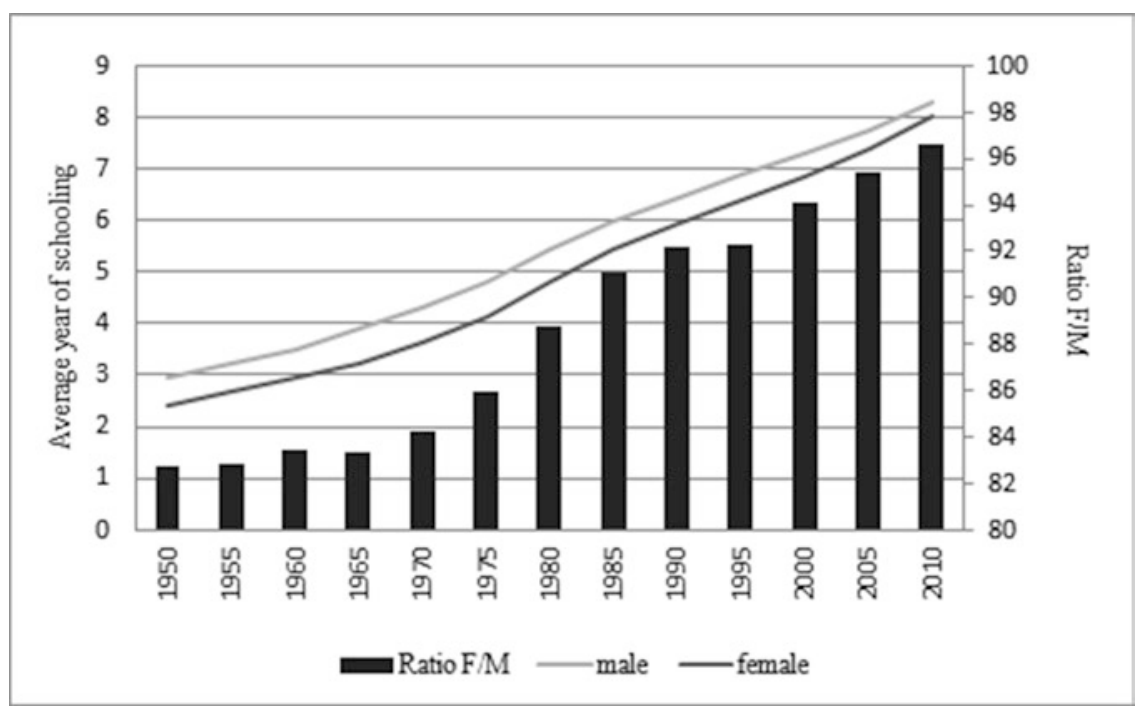

Fig. 1 Education attainment by sex. Sources: Based on Barro, R. J. and J. W. Lee (2012)

Figure 1 shows the evolution of education during the period of analysis, comparing average female to average male schooling. Both sexes improved but girls had not yet reached the boys' levels. The gender catching up in schooling started with the massive intake of women into primary education; it advanced with greater female participation in secondary education and progressed still further with more and more women at the higher education level.

However, when we examine the countries individually we find differences among them. One group of countries started the period with an average of years of study almost twice as high as the others. These were Argentina, Chile and Uruguay and to a lesser degree Costa Rica. This group implemented public policies to promote the enrolment of boys and girls in primary and secondary education. This resulted in sustained growth in years of schooling for both sexes during the second half of the twentieth century and women in Argentina and Uruguay performed even better than male.

In the second half of the century, another group of countries had average schooling of only 2 years, and girls still lagged behind boys even at the end of the period. This group included countries with larger indigenous and rural populations, and this may help explain why enrolment in formal educational institutions was so low. The group contains countries like Guatemala, Honduras, El Salvador and Nicaragua.

Mexico and Brazil are examples of good improvement in the period. The populations of both had low education levels in the late 1950s, but by the end of the period years of schooling had increased greatly in both. Although the causality has to be firmly established, it appears that rapid economic growth raised the demand for schooling during the period, and that both were proactive in education policies intended to improve human capital fast. 
The relationship between activity rates and education has not been linear. At low levels of schooling, there is a strong correspondence between years of schooling and female labour force participation. At higher levels of female years of schooling the elasticity of the female activity rate decreases.

Although average years of schooling increased in most of the Latin American countries during the period, there are big differences in the sample. In 2000 Chile and Costa Rica had high schooling rates and low activity rates, while Bolivia, Ecuador, Paraguay and El Salvador had high activity rates but only modest increases in years of schooling. Towards the end of the period the countries in the region returned to the free market model and opened up to trade. This shift increased the demand for technical skills and reduced the demand for low-skill workers, a sector in which the percentage of women is higher than the percentage of female economywide (Bértola and Ocampo 2012).

\section{Measuring Inequality and the Gender Wage Gap}

Although overall female labour force participation has increased over the last 50 years, there are still gender differences among countries. Gender discrimination in wages has persisted over time and is common in many countries. The persistence suggests structural causes rooted in institutions and cultural norms. For instance, women are more likely to respond positively to increased economic opportunities in the labour market when childcare services are available or when their participation is socially accepted. In contrast, where significant barriers remain their progress is more limited (Fig. 2).

In the first decade of the twenty-first century, Latin American women typically received less than $35 \%$ of total national income, although the figure was around $40 \%$ in six leaders (Fig. 3). The women's share increased strongly between 1990 and 2000 in Costa Rica, Ecuador, El Salvador, Honduras, Uruguay and Venezuela. In Costa Rica, Ecuador and El Salvador the reason behind this trend is more related to improvements in the female activity rate than to a narrowing of the gender wage gap but in Guatemala, Honduras, Uruguay and Venezuela the gap became considerably smaller during this period (Fig. 4).

In the first decade of the new century the countries with the narrowest wage gaps were Argentina, Colombia, Costa Rica, Guatemala, Honduras, Uruguay and Venezuela.

The other countries in our sample are falling behind. We can only partially reconstruct some countries' trajectories because sources are scarce. The data we have indicates that the countries that had a narrower gender wage gap in the past are the ones performing better at present. In the period 1970-2010 the gap in Brazil was wider than that in Argentina or Uruguay.

In Latin America, inequality among men has more weight in the total Gini level due to their greater participation in the labour market and to greater inequality among males (see Appendices 1, 2 and 3). The distribution of schooling and skills among sexes may be part of the explanation. 


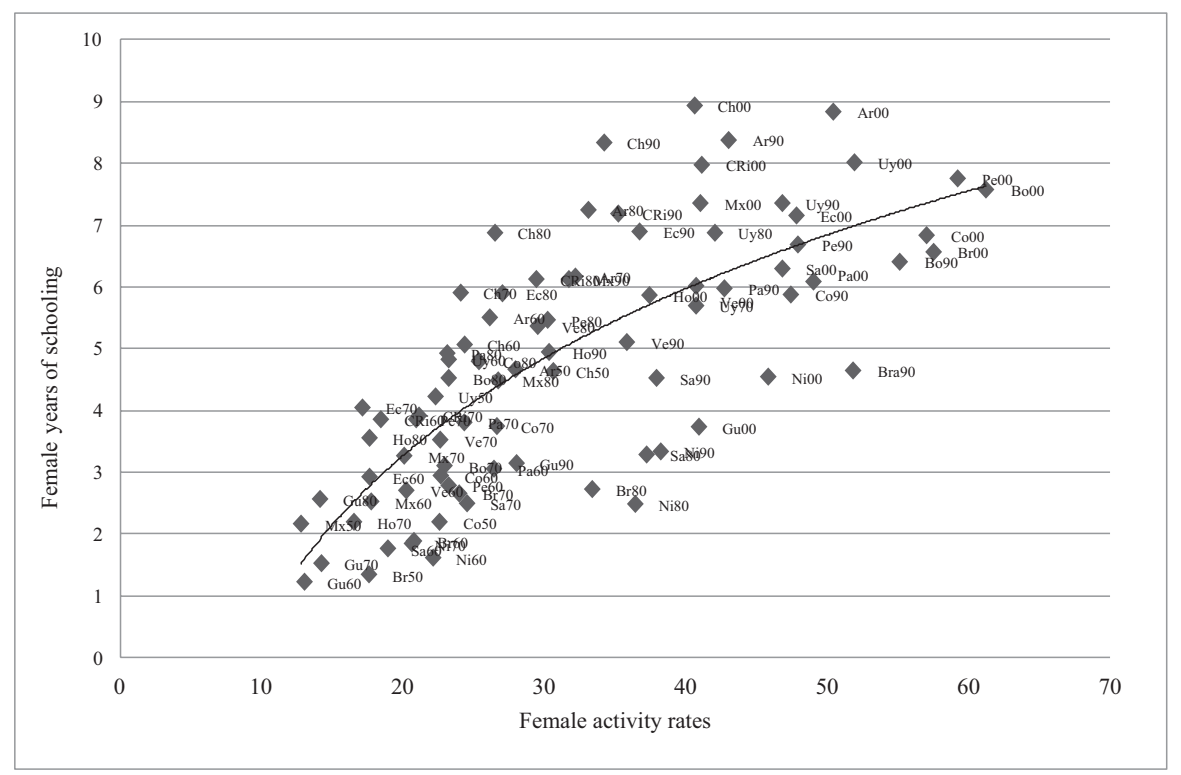

Fig. 2 Female activity rate and years of schooling, 1950-2000. Sources: Activity rates idem Table 1. Years of schooling - Barro and Lee (2012)

There is no a clear trend in the evolution of inequality among women. While the overall average remains unchanged over the period, there is a group of countries (Argentina, Uruguay, Costa Rica, Venezuela and Peru) with increasing inequality in women's wages. The overall inequality increase during the period probably affects women as well as men. The reason the spread among women's wages is greater is probably that they join the labour market with greater human capital because their years of schooling and work experience are increasing.

\section{Explaining the Gender Wage Gap}

In an international comparison, Blau and Kahn (1997) found that labour markets with highly unequal rates of remuneration also have high levels of gender inequality. Next we tested their relation between overall wage inequality and gender gap for Latin America.

At first glance, Latin American evidence confirms the postulated relation. The countries that are more unequal (with Gini ratings above 0.5: Fig. 5) also have wider gender gaps. When we look at the differences among countries over the period we can identify two groups. First, there are those in which overall inequality remained relatively high over the period and the gender gap narrowed but female wage earnings 


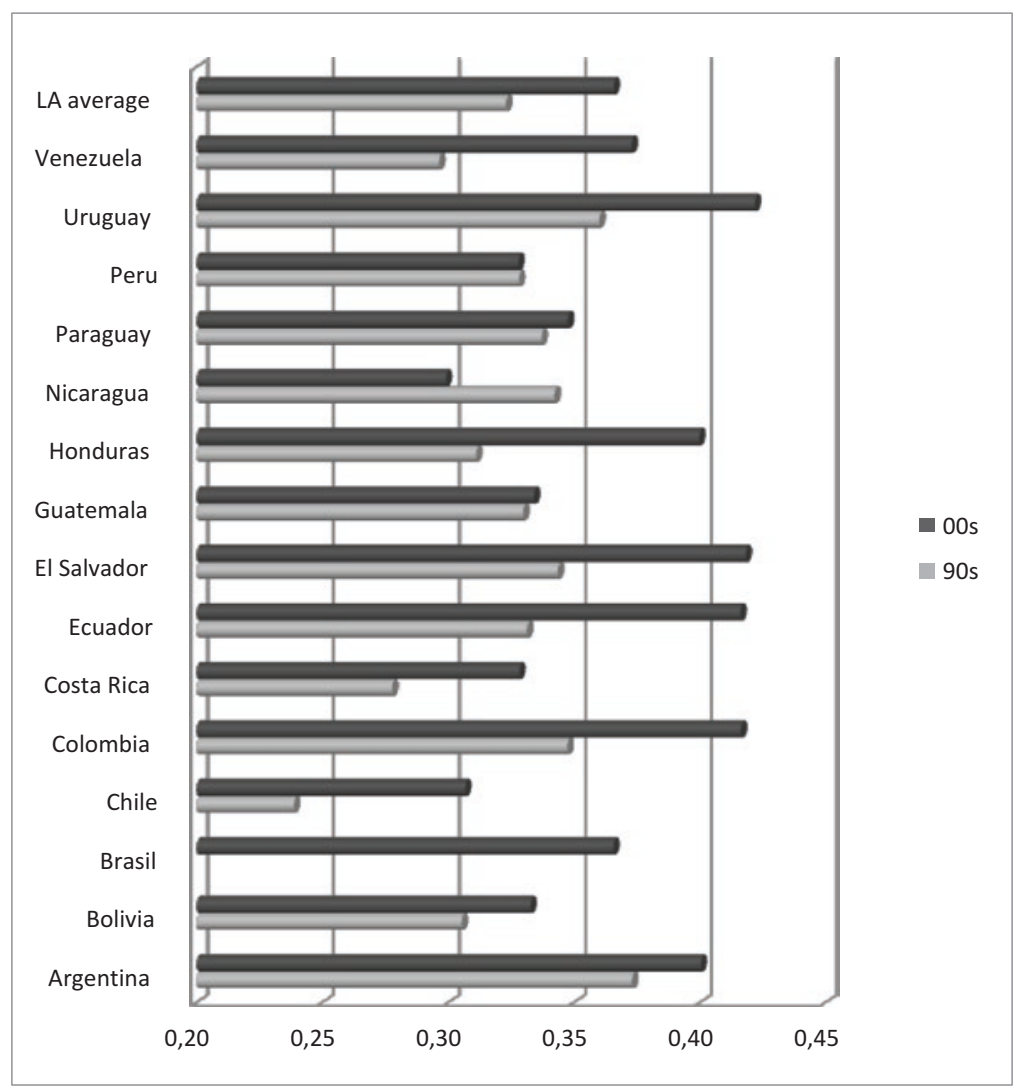

Fig. 3 Women's share of wage bill, 1990-2000. Sources: Household surveys

remained lower than male. This was the case in Chile, Bolivia, Honduras, Peru, Nicaragua and Ecuador. Brazil was a special case with high inequality and a wide gender gap (see Appendices 1, 2 and 3).

There is a second group with relatively low total inequality and a narrowing gender gap, and here we find Argentina, Uruguay, Costa Rica and Venezuela. In particular, Argentina and Uruguay are also countries with a lower gender gap in the past and a higher activity rate. In any case, path dependence does not seem to be the only way to achieve a narrower gender gap: Venezuela belongs to this group although traditionally it has had low female participation rate.

Another factor that probably impacts on the gender wage gap is the historical pattern of women's participation in the labour market. In the period 1940-1970, gender inequality was high in Latin America and this was expressed in a low level of female labour participation and a wide gender gap. There are few data available 


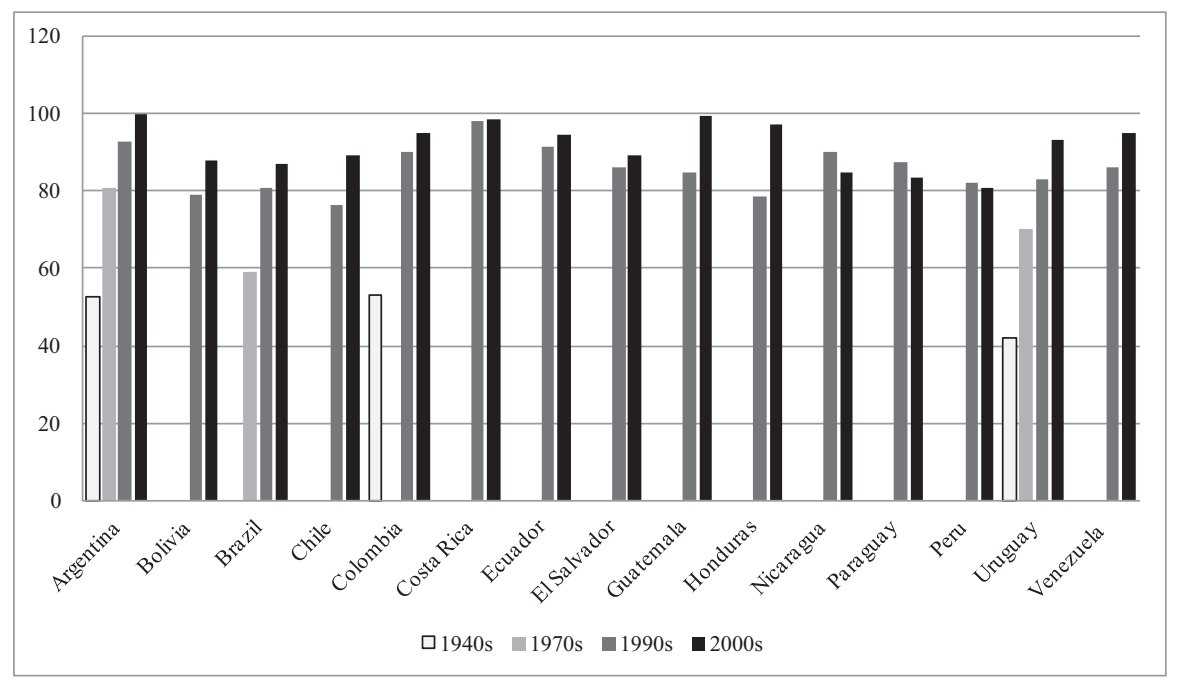

Fig. 4 Gender wage gap in Latin America, 1940-2000. Sources: ILO and household surveys

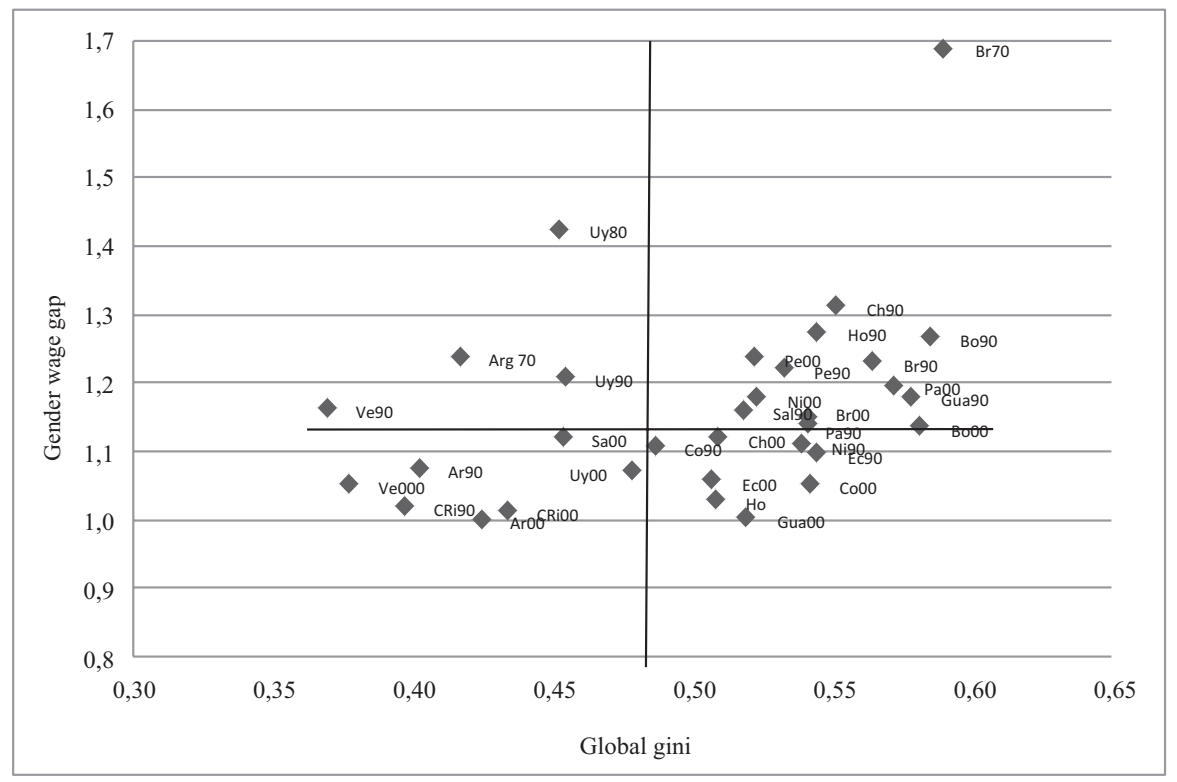

Fig. 5 Overall inequality and gender wage gap. Sources: Household surveys 


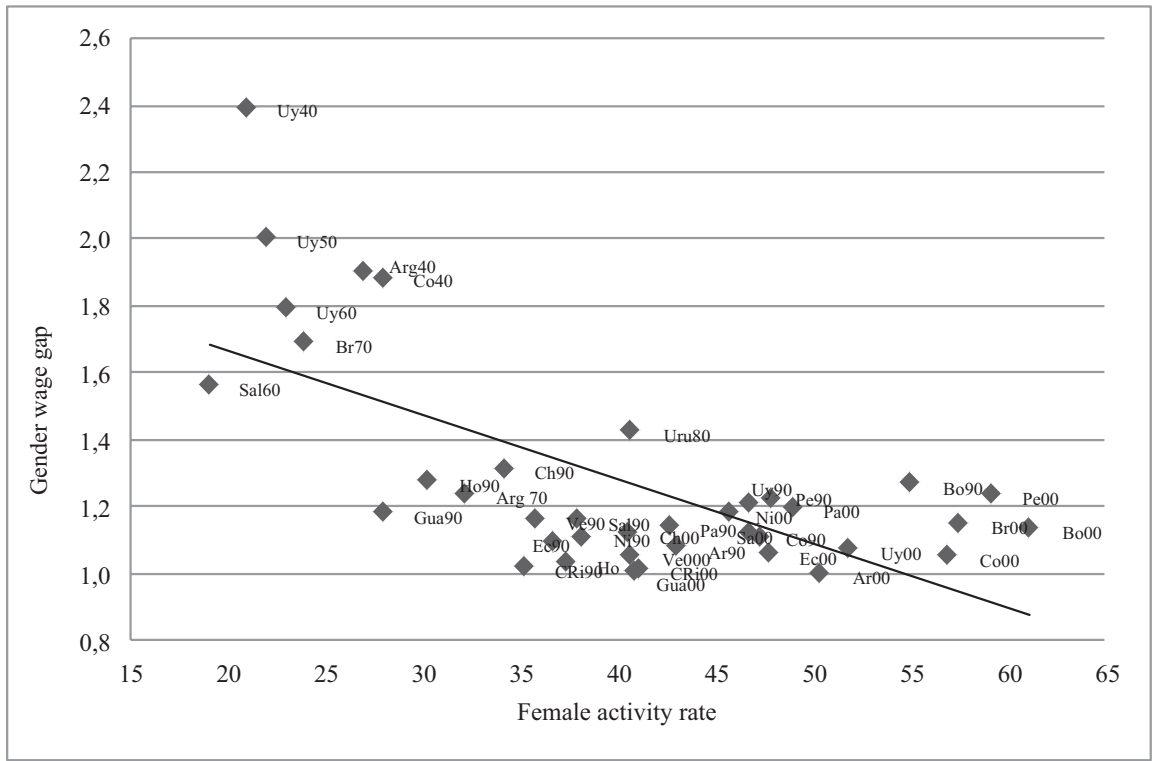

Fig. 6 Female activity rate and gender wage gap, 1940-2000. Sources: Activity rates idem Table 1. Gender wage gap: ILO and household surveys

for the 1980s, the so-called lost decade, and in the 1990s we entered a new phase with a narrower gender wage gap and greater variability in women's activity rates across the region. At the end of the period women's participation in labour markets was still rising but the gender gap had not significantly narrowed. It can be seen that this correlation between the two variables is not very strong towards the end of the period in which many countries have similar gender gaps and there is a wide spread in the participation rate.

The trends in women activity rates in Latin American labour markets in 2000s are very different between countries. While the general trend is rising over time, only in very few cases does the average reach $50 \%$. The heterogeneity revealed in Fig. 6 could have many explanations and is probably linked to the liberal deregulatory economic policies prevailing since the 1980s. But the gender gap remained stable in the 1990s and 2000s.

These results also show that increases in women's participation in the labour market do not necessarily mean a substantial change because as the participation rate increases the female occupation and wage dispersion also increase. Gender gap trends depend on individual investment in education and the returns to that education. In recent years, female education levels have risen relative to those of men. Although countries have achieved high female labour market participation rates, it is clear that educational equality is not sufficient to secure gender parity in income. One of the reasons why the gender gap has persisted is that it tends to be wider at 
higher levels of education. The evolution of the wage gap between men and women is different at different educational levels. In the tertiary education group the gender gap was wide at the start of the period and there was little subsequent improvement, which shows the glass ceiling effect, whereas in the group with only primary education the gap narrowed more during the same period.

Women's education improved considerably in the 1990s but, as we saw above, the increasing skill premium that accompanied the new economic model was less favourable for better educated women. Increasing female labour force participation and improved educational attainment in a context of relatively stable male labour force participation and educational attainment contributed to an overall narrowing of the gap. As we saw above, a steady convergence between the wages of women and those of men is not automatic. The portion of the wage gap that cannot be explained by labour market characteristics related to workers' skills is generally attributed to discrimination and to differences in preferences between men and women. Women tend to enter different careers than men.

There is still a tendency for occupations to be "male dominated" or "female dominated," and the female-dominated ones tend to pay less even when men and women have the same educational level. The majority of women work in the services and agricultural sectors, and the fact is that areas in which women are the vast majority - secretaries, teachers and nurses - are poorly paid.

In the last 50 years, schooling levels have increased and the upgrading of the occupational structure as a result of technological changes and economic growth has created a demand for more skilled and educated labour. The increasing demand for a skilled and highly educated labour has resulted, among other things, in policies to raise the overall educational level of the population. In spite of that Fig. 7 shows a high level of sex segregation persisting among employees with tertiary education, despite the relative equalization between men and women in overall level of educational attainment. There are wage disparities between men and women with the same educational qualifications in all Latin American countries analyzed and at all educational levels, but in particular among the more educated population.

Our in-depth study of the wage gap between men and women shows that the biggest differences that remain are among those with the highest levels of qualifications and incomes (Fig. 8). When we compare the evolution of the gender gap among the more educated population in the decade of 1990s and 2000s, we find that although the differences decrease, men's average wages stayed at around 25 percentage points higher than women's. At the end of that decade there were still large wage differentials between men and women with the same level of educational attainment.

In the light of these results, whether these wage differences in the group of tertiary education are related to women's human capital being underused in the labour market. One way to approach this is to examine the distribution of the most highly educated peoples by their income levels. However, we have been able to confirm that $80-90 \%$ of people of both sexes with tertiary education levels are in the highest wage level (see Appendices 1, 2 and 3). Even though our data do not show the structure of occupations by sex inside the group of high income level, we can assume that this might be different among female and males. 


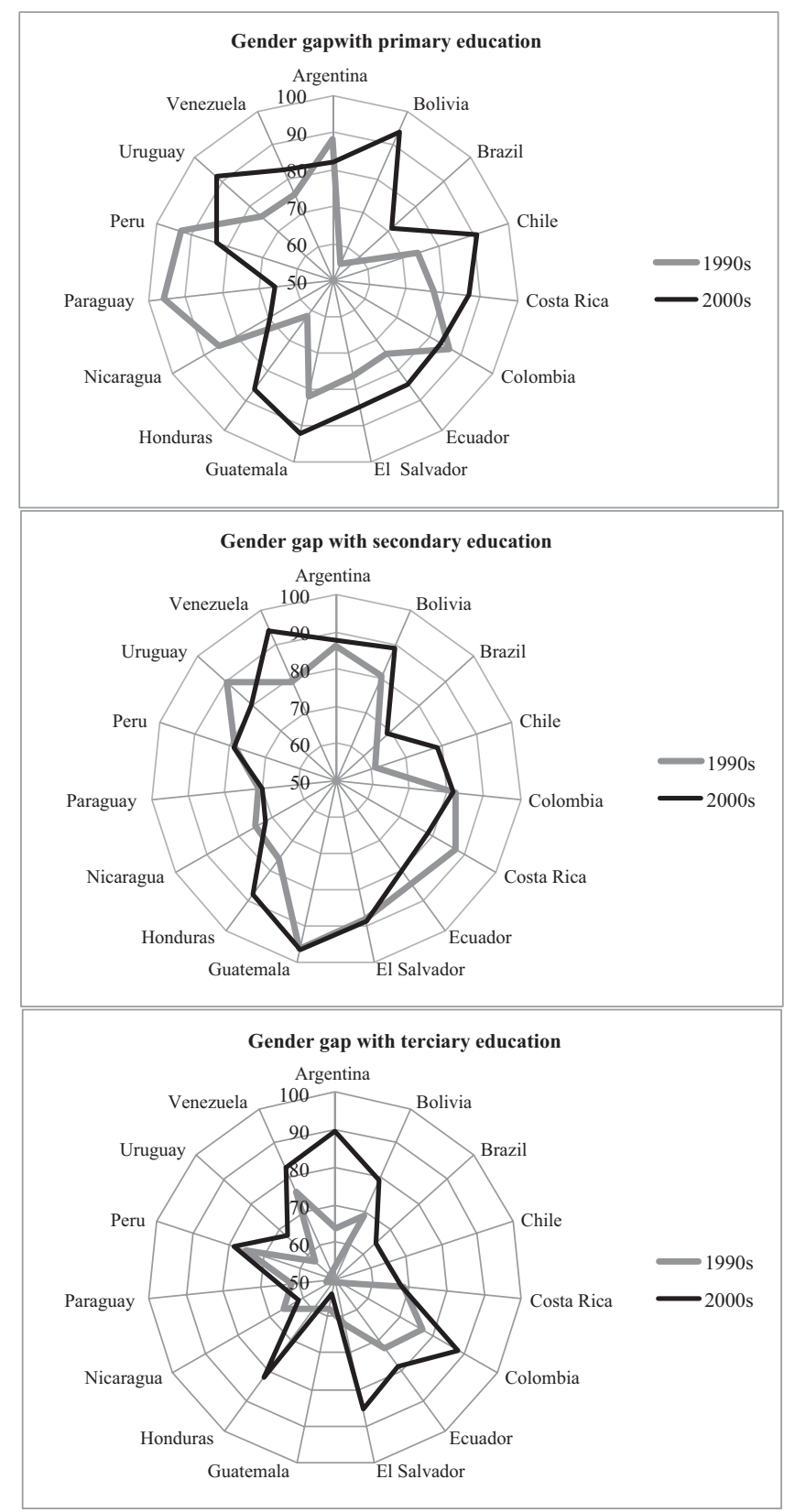

Fig. 7 Education and the gender gap. Sources: ILO and household surveys 


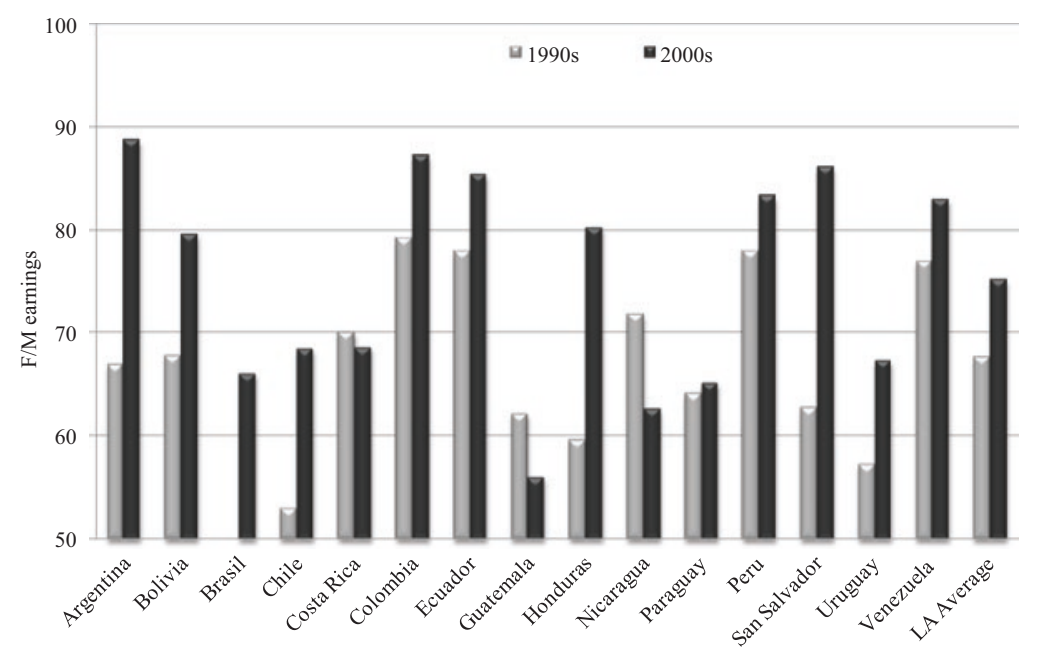

Fig. 8 Gender wage gap among people with high wage levels and tertiary education. Sources: Household surveys. Note: Population was classified according to their wages in three levels: low, middle and high

\section{Conclusion}

The aim of this chapter has been to help to bring the gender perspective into the discussion of the evolution of overall inequality. Our results enable us to map trends in female labour participation rates and schooling achievement in Latin America in the twentieth century.

First we find that the most unequal countries are also those with the greater gender wage gap, and recent history reveals much inertia. The most "advanced" countries in terms of gender equality are those in which female labour participation rates increased in the first half of the twentieth century and also have higher levels of educational attainment and a narrower gender wage gap. In the less "advanced" countries, women's entry into the labour market lagged behind that of the advanced group average, and this was associated with less developed economies with large indigenous and black population.

These results suggest that labour market structures are different in the two groups and that a narrowing of the gender gap does not depend only on women's participation at the end of the period but also on path dependence in labour occupational segregation. Contrary to what we expected, the gender gap widens gradually throughout as years of schooling rise.

The increased participation of women in the labour market impacts overall inequality: while their share of the wage bill has increased and they have gradually 
moved up the educational ladder, they have found the more skilled occupations to have higher gender wage gaps so that overall inequality has risen on that account.

Interestingly, the group that combines high wages with the highest average years of schooling is also the most resistant to this egalitarian trend. It seems that this group does not obey a logic that is purely economic but that there is an invisible barrier against incorporating these new actors into decision-making positions. 


\section{Appendix 1: Gender Inequality}

\begin{tabular}{|c|c|c|c|c|c|c|c|c|}
\hline & Country & Year & $\begin{array}{l}\text { Inequality } \\
\text { measures } \\
(\%)\end{array}$ & & & $\begin{array}{l}\text { Income } \\
\text { share } \\
(\%)\end{array}$ & & $\begin{array}{l}\text { Gender } \\
\text { gap }\end{array}$ \\
\hline & & & Total & Men & Women & Men & Women & \\
\hline \multirow[t]{14}{*}{ 1990s } & Argentina & 1992 & 0.40 & 0.41 & 0.39 & 0.63 & 0.37 & 93 \\
\hline & Bolivia & 1997 & 0.59 & 0.60 & 0.55 & 0.69 & 0.31 & 79 \\
\hline & Chile & 1990 & 0.55 & 0.56 & 0.52 & 0.76 & 0.24 & 76 \\
\hline & Colombia & 1996 & 0.49 & 0.49 & 0.47 & 0.65 & 0.35 & 90 \\
\hline & Costa Rica & 1992 & 0.40 & 0.39 & 0.42 & 0.72 & 0.28 & 98 \\
\hline & Ecuador & 1995 & 0.54 & 0.53 & 0.57 & 0.67 & 0.33 & 91 \\
\hline & El Salvador & 1991 & 0.52 & 0.51 & 0.53 & 0.66 & 0.34 & 86 \\
\hline & Guatemala & 2000 & 0.58 & 0.56 & 0.60 & 0.67 & 0.33 & 85 \\
\hline & Honduras & 1997 & 0.54 & 0.56 & 0.50 & 0.69 & 0.31 & 78 \\
\hline & Nicaragua & 1993 & 0.54 & 0.57 & 0.49 & 0.36 & 0.34 & 90 \\
\hline & Paraguay & 1997 & 0.54 & 0.55 & 0.53 & 0.66 & 0.34 & 88 \\
\hline & Peru & 1997 & 0.53 & 0.54 & 0.52 & 0.67 & 0.33 & 82 \\
\hline & Uruguay & 1992 & 0.45 & 0.45 & 0.45 & 0.64 & 0.36 & 83 \\
\hline & Venezuela & 1992 & 0.37 & 0.36 & 0.36 & 0.70 & 0.30 & 86 \\
\hline \multirow[t]{15}{*}{$2000 \mathrm{~s}$} & Argentina & 2006 & 0.43 & 0.42 & 0.43 & 0.60 & 0.40 & 100 \\
\hline & Bolivia & 2005 & 0.58 & 0.58 & 0.58 & 0.67 & 0.33 & 88 \\
\hline & Brazil & 2008 & 0.54 & 0.55 & 0.53 & 0.63 & 0.37 & 87 \\
\hline & Chile & 2006 & 0.51 & 0.51 & 0.51 & 0.69 & 0.31 & 89 \\
\hline & Costa Rica & 2006 & 0.43 & 0.43 & 0.45 & 0.67 & 0.33 & 99 \\
\hline & Colombia & 2006 & 0.54 & 0.54 & 0.54 & 0.58 & 0.42 & 95 \\
\hline & Ecuador & 2006 & 0.51 & 0.49 & 0.53 & 0.58 & 0.42 & 95 \\
\hline & El Salvador & 2005 & 0.45 & 0.46 & 0.45 & 0.58 & 0.42 & 89 \\
\hline & Guatemala & 2006 & 0.52 & 0.52 & 0.51 & 0.67 & 0.33 & 100 \\
\hline & Honduras & 2006 & 0.51 & 0.51 & 0.50 & 0.60 & 0.40 & 97 \\
\hline & Nicaragua & 2005 & 0.52 & 0.55 & 0.45 & 0.70 & 0.30 & 85 \\
\hline & Peru & 2006 & 0.52 & 0.53 & 0.51 & 0.67 & 0.33 & 81 \\
\hline & Paraguay & 2007 & 0.57 & 0.59 & 0.54 & 0.65 & 0.35 & 84 \\
\hline & Uruguay & 2006 & 0.48 & 0.49 & 0.47 & 0.58 & 0.42 & 93 \\
\hline & Venezuela & 2006 & 0.38 & 0.36 & 0.40 & 0.63 & 0.37 & 95 \\
\hline $\begin{array}{l}\text { Average } \\
1990 \mathrm{~s}\end{array}$ & 0.50 & 0.51 & 0.49 & 0.66 & 0.32 & 86 & & \\
\hline $\begin{array}{l}\text { Average } \\
2000 \mathrm{~s}\end{array}$ & 0.50 & 0.50 & 0.49 & 0.63 & 0.37 & 92 & & \\
\hline
\end{tabular}

Sources: Household surveys 


\section{Appendix 2: Gender Inequality in High Income Level and Tertiary Education Population}

\begin{tabular}{|c|c|c|c|c|c|c|c|}
\hline & \multirow[t]{2}{*}{ Country } & \multicolumn{3}{|c|}{ Inequality measures (\%) } & \multirow{2}{*}{$\begin{array}{l}\text { Income share } \\
(\%) \\
\text { Men }\end{array}$} & \multirow[b]{2}{*}{ Women } & \multirow[t]{2}{*}{ Gender gap } \\
\hline & & Total & Men & Women & & & \\
\hline \multirow[t]{14}{*}{$1990 \mathrm{~s}$} & Argentina & 0.35 & 0.38 & 0.29 & 0.54 & 0.46 & 67 \\
\hline & Bolivia & 0.41 & 0.43 & 0.34 & 0.68 & 0.32 & 68 \\
\hline & Chile & 0.49 & 0.50 & 0.38 & 0.76 & 0.24 & 53 \\
\hline & Colombia & 0.38 & 0.40 & 0.32 & 0.63 & 0.37 & 70 \\
\hline & Costa Rica & 0.31 & 0.31 & 0.29 & 0.68 & 0.32 & 79 \\
\hline & Ecuador & 0.38 & 0.38 & 0.37 & 0.66 & 0.34 & 78 \\
\hline & El Salvador & 0.40 & 0.42 & 0.28 & 0.76 & 0.24 & 63 \\
\hline & Guatemala & 0.44 & 0.45 & 0.35 & 0.79 & 0.21 & 62 \\
\hline & Honduras & 0.41 & 0.43 & 0.30 & 0.72 & 0.28 & 60 \\
\hline & Nicaragua & 0.47 & 0.47 & 0.44 & 0.69 & 0.31 & 72 \\
\hline & Paraguay & 0.44 & 0.46 & 0.35 & 0.70 & 0.30 & 64 \\
\hline & Peru & 0.38 & 0.40 & 0.32 & 0.66 & 0.34 & 78 \\
\hline & Uruguay & 0.40 & 0.40 & 0.32 & 0.61 & 0.39 & 57 \\
\hline & Venezuela & 0.25 & 0.25 & 0.23 & 0.63 & 0.37 & 77 \\
\hline \multirow[t]{15}{*}{$2000 \mathrm{~s}$} & Argentina & 0.28 & 0.30 & 0.26 & 0.45 & 0.55 & 89 \\
\hline & Bolivia & 0.38 & 0.41 & 0.31 & 0.64 & 0.36 & 80 \\
\hline & Brazil & 0.46 & 0.47 & 0.42 & 0.57 & 0.43 & 66 \\
\hline & Chile & 0.48 & 0.50 & 0.42 & 0.63 & 0.37 & 68 \\
\hline & Costa Rica & 0.33 & 0.35 & 0.27 & 0.61 & 0.39 & 69 \\
\hline & Colombia & 0.40 & 0.41 & 0.39 & 0.51 & 0.49 & 87 \\
\hline & Ecuador & 0.47 & 0.43 & 0.51 & 0.59 & 0.41 & 85 \\
\hline & El Salvador & 0.30 & 0.34 & 0.26 & 0.50 & 0.50 & 86 \\
\hline & Guatemala & 0.45 & 0.46 & 0.32 & 0.77 & 0.23 & 56 \\
\hline & Honduras & 0.36 & 0.36 & 0.34 & 0.60 & 0.40 & 80 \\
\hline & Nicaragua & 0.47 & 0.50 & 0.40 & 0.67 & 0.33 & 63 \\
\hline & Paraguay & 0.40 & 0.43 & 0.34 & 0.62 & 0.38 & 65 \\
\hline & Peru & 0.38 & 0.41 & 0.32 & 0.63 & 0.37 & 83 \\
\hline & Uruguay & 0.39 & 0.42 & 0.34 & 0.47 & 0.53 & 67 \\
\hline & Venezuela & 0.28 & 0.32 & 0.25 & 0.49 & 0.51 & 83 \\
\hline \multicolumn{2}{|c|}{ Average 1990s } & 0.39 & 0.41 & 0.33 & 0.68 & 0.32 & 68 \\
\hline \multicolumn{2}{|c|}{ Average 2000s } & 0.39 & 0.41 & 0.33 & 0.58 & 0.42 & 75 \\
\hline
\end{tabular}

Sources: Household surveys 


\section{Appendix 3: Distribution of the Population with Tertiary Education According to Income}

\begin{tabular}{|c|c|c|c|c|c|c|c|}
\hline & \multirow[t]{3}{*}{ Country } & \multicolumn{6}{|c|}{ Income levels } \\
\hline & & \multicolumn{3}{|c|}{ Men } & \multicolumn{3}{|c|}{ Women } \\
\hline & & Low & Medium & High & Low & Medium & High \\
\hline \multirow[t]{13}{*}{$1990 \mathrm{~s}$} & Argentina & 24.6 & 11.0 & 64.4 & 23.2 & 17.7 & 59.1 \\
\hline & Bolivia & 2.5 & 16.7 & 80.8 & 3.3 & 17.4 & 79.3 \\
\hline & Chile & 4.0 & 10.4 & 85.6 & 7.6 & 21.0 & 71.4 \\
\hline & Colombia & 1.8 & 7.5 & 90.7 & 1.6 & 12.3 & 86.1 \\
\hline & Costa Rica & 0.9 & 5.6 & 93.5 & 4.4 & 5.9 & 89.7 \\
\hline & El Salvador & 2.5 & 3.1 & 94.4 & 1.1 & 6.5 & 92.5 \\
\hline & Guatemala & 4.4 & 4.4 & 91.2 & 5.8 & 10.7 & 83.5 \\
\hline & Honduras & 1.5 & 5.8 & 92.7 & 0.0 & 8.8 & 91.2 \\
\hline & Nicaragua & 1.7 & 16.9 & 81.4 & 3.5 & 25.6 & 70.9 \\
\hline & Paraguay & 0.6 & 1.7 & 97.8 & 0.0 & 7.8 & 92.2 \\
\hline & Peru & 5.8 & 20.2 & 74.0 & 8.0 & 23.6 & 68.3 \\
\hline & Uruguay & 5.8 & 14.2 & 80.0 & 4.6 & 21.3 & 74.1 \\
\hline & Venezuela & 5.6 & 11.1 & 83.3 & 5.6 & 11.1 & 83.3 \\
\hline \multirow[t]{15}{*}{$2000 \mathrm{~s}$} & Argentina & 8.8 & 19.4 & 71.8 & 10.5 & 19.4 & 70.1 \\
\hline & Bolivia & 2.4 & 7.5 & 90.1 & 3.7 & 9.0 & 87.3 \\
\hline & Brazil & 4.6 & 9.5 & 85.9 & 4.6 & 12.0 & 83.5 \\
\hline & Chile & 5.5 & 11.8 & 82.7 & 8.6 & 16.6 & 74.8 \\
\hline & Costa Rica & 2.8 & 2.4 & 94.8 & 2.1 & 5.9 & 91.9 \\
\hline & Colombia & 6.1 & 13.3 & 80.7 & 7.0 & 12.2 & 80.8 \\
\hline & Ecuador & 13.1 & 15.6 & 71.3 & 21.1 & 15.8 & 63.2 \\
\hline & El Salvador & 11.5 & 5.3 & 83.2 & 7.3 & 7.0 & 85.7 \\
\hline & Guatemala & 1.4 & 3.4 & 95.2 & 5.6 & 5.0 & 89.4 \\
\hline & Honduras & 4.8 & 5.3 & 89.9 & 4.3 & 3.2 & 92.5 \\
\hline & Nicaragua & 4.5 & 6.2 & 89.3 & 4.7 & 9.2 & 86.1 \\
\hline & Paraguay & 2.7 & 8.0 & 89.4 & 4.4 & 9.1 & 86.6 \\
\hline & Peru & 8.0 & 21.1 & 70.9 & 12.5 & 23.2 & 64.3 \\
\hline & Uruguay & 5.6 & 11.4 & 83.0 & 5.7 & 12.8 & 81.5 \\
\hline & Venezuela & 4.6 & 16.2 & 79.3 & 6.0 & 17.6 & 76.5 \\
\hline
\end{tabular}

Sources: Household surveys

Open Access This chapter is distributed under the terms of the Creative Commons Attribution 4.0 International License (http://creativecommons.org/licenses/by/4.0/), which permits use, duplication, adaptation, distribution and reproduction in any medium or format, as long as you give appropriate credit to the original author(s) and the source, a link is provided to the Creative Commons license and indicate if changes were made.

The images or other third party material in this chapter are included in the work's Creative Commons license, unless indicated otherwise in the credit line; if such material is not included in the work's Creative Commons license and the respective action is not permitted by statutory regulation, users will need to obtain permission from the license holder to duplicate, adapt or reproduce the material.

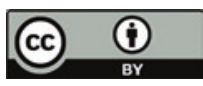




\section{References}

Artecona, R., \& Cunningham, W. (2002). Effects of trade liberalization on the gender wage gap in Mexico. Working Paper, The World Bank Development Group.

Barro, R. J., \& Lee, J.-W. (2012). A new data set of educational attainment in the world, 1950-2010. Journal of Development Economics, 104, 184-198.

Beneria, L. (2003). Gender, development and globalization. Economics as if all people mattered. New York: Rouledge.

Beneria, L., Floro, M., Grow, C., \& MacDonald, M. (2000). Globalization and gender. Feminist Economics, 63(3), VII-XVIII.

Bergmann, B. R. (1974). Occupational segregation, wages and profits when employers discriminate by race or sex. Eastern Economic Journal, 1(2), 103-110.

Berik, G., van der Meulen Rodgers, Y., \& Zveglich Jr. J. (2003). International trade and wage discrimination: Evidence from East Asia. World Bank Policy Research, Working Paper.

Bértola, L., \& Ocampo, J. A. (2012). The economic development of Latin America since independence. Oxford: Oxford University Press.

Blau, F. D., \& Kahn, L. M. (1997). Swimming upstream: Trends in the gender wage differential in the 1980's. Journal of Labor Economics, 15(1), 1-42.

Bourguignon, F., Ferreira, F. H. G., \& Lustig, N. (Eds.). (2004). The microeconomics of income distribution dynamics in East Asia and Latin America. Washington, DC: World Bank.

Bourguignon, F., \& Morrison, C. (2002). Income distribution among world citizens: 1820-1990. American Economic Review, 92(September), 1113-1132.

Çağatay, N., \& Ertürk, K. (2004). Gender and globalization: A macroeconomic perspective. Working Paper No. 19. Geneva: ILO.

Camou, M. M. (2010). Las instituciones del mercado de trabajo en dos ramas de la industria uruguaya, 1900-1960. Facultad de Ciencias Sociales, Montevideo, Universidad de la República. Tesis de Doctorado.

Camou, M. M. (2012). Historical patterns of gender inequality in Latin America: New evidence. 16th World Economic History Congress.

Camou, M. M., \& Maubrigades, S. (2013). Desigualdades de género y desarrollo en América Latina en el S.XX: su historia a través de indicadores del desarrollo humano. Revista del Centro de Estudios Interdisciplinarios Latinoamericanos (CEIL) vol vii, no. 2 (diciembre 2013) (pp208-238).

Camps, E., Camou, M., Maubrigades, S., \& Mora-Sitja, N. (2006). Globalization and wage inequality in South and East Asia, and Latin America: A gender approach. Working Paper No. 970, Departamento de Economía y Empresas, Universidad Pompeu Fabra, Barcelona.

Deininger, K., \& Squire, L. (1996). A new data set measuring income inequality. The World Bank Economic Review, 10(3), 565-591.

Deininger, K., \& Squire, L. (1998). New ways of looking at old issues: Inequality and growth. Journal of Development Economics, 57(2), 259-288.

Dell, M. (2005, December). Widening the border: The impact of Nafta on female labor force participation in Mexico. Oxford University WP.

Espino, A., \& Azar, P. (2007). Cambios de la política económica desde una perspectiva de género: de la sustitución de importaciones a la apertura económica. 1er Congreso Latinoamericano de Historia Económica, Montevideo.

Fleitas, S., \& Román, C. (2010). Evolución de la población económicamente activa en el siglo XX:un análisis de la estructura por por sexo, edad y generaciones. Boletín de Historia Económica, No. 9.

Gálvez, T. (2001). Aspectos económicos de la equidad de género. CEPAL.

Garcia Cuellar, R. (2001). Essays on the effects of trade and location on the gender gap: A study of the Mexican labor market. Doctoral Dissertation, Harvard University, Economics Department.

Goldin, C. (1994). The U-shaped female Labor force function in economic development and economic history. NBER Working Paper \#4707. 
Goldin, C. (2000). Labor markets in the twentieth century. In S. Engerman \& R. Gallman (Eds.), The Cambridge economic history of the United States (pp. 549-624). Cambridge: Cambridge University Press.

Goldin, C. (2006). The quiet revolution that transformed women's employment, education, and family. The American Economic Review, 96(2), 1-21.

Higgins, M., \& Williamson, J. G. (2002). Explaining inequality: The world round: Cohort size, kuznets curves, and openness. Journal of Southeast Asian Studies, 40(30), 268-302.

Hoyos, A., \& Nopo, H. (2010). Evolution of gender gaps in Latin America at the turn of the twentieth century. IDB Working Paper Series.

Joekes, S. (1999). A gender-analytical perspective on trade and sustainable development. In UNCTAD, Trade, sustainable development and gender (pp. 33-59). New York and Geneva: UNCTAD.

O’Neill, J., \& Polachek, S. (1993). Why the gender wages gap narrowed in the 1980's. Journal of Labor Economics, 11(1), 205-228.

Oaxaca, R. (1973). Male-female wage differentials in urban labor markets. International Economic Review, 14, 693-709.

Olivetti, C. (2013). The female labor force and long-run development: The American experience in comparative perspective. National Bureau of Economic Research.

Pampel, F. C., \& Tanaka, K. (1986). Economic development and female labor force participation: A reconsideration. Social Forces, 64(3), 599-619.

Psacharopoulos, G., \& Tzannatos, Z. (1989). Female labor force participation: An international perspective. World Bank Research Observer, 4(2), 187-201.

Reyes Campo, N. (2012). Women wages and the gender gap during the import substitution industrialization in Chile. Barcelona: Universidad de Barcelona.

Sarasúa, C., \& Gálvez, L. (2003). Privilegios o Eficiencia, Mujeres y Hombres en los Mercados de Trabajo. In C. Sarasúa, \& L. Gálvez (Eds.), Introducción. ¿Privilegios o eficiencia? Mujeres y hombres en el mercado de trabajo (pp. 9-33). Alicante: Universidad de Alicante.

Sala-i-Martin, X. (2003). The disturbing "Rise” of global income inequality. NBER WP.

Samuelson, P. (1948). International trade and the equalization of factor prices. The Economic Journal, 58, 163-184.

Schultz, T. P. (1990). Women's changing participation in the labor force: A world perspective. Economic Development and Cultural Change, 38, 457-488.

Seguino, S. (2000). Gender inequality and economic growth: A cross-country analysis. World Development, 28(7), 1211-1230.

Todaro, R. (2004). Chile under a gender lens: from import substitution to open markets, Unrisd.

Tzannatos, Z. (1999). Women and labor market changes in the global economy: Growth helps, inequalities hurt and public policy matters. World Development, 27(3), 551-569.

World Bank. (1995). World Development Report 1995: Workers in an integrating world. Oxford University Press: New York.

María Magdalena Camou has a Ph.D. in Economic History from Universidad de la República, Uruguay, where she is a Professor in the Economic and Social History Program. Her main research lines are labor markets during industrialization, international comparative wages, living standards, and gender inequality. She is one of the authors and editors of Gender Inequalities and Development in Latin America During the Twentieth Century and several other books and articles.

Silvana Maubrigades is a Sociologist. She holds an M.A. in Economic History and is a Ph.D. candidate in Social Sciences with mention in Economic History from Universidad de la República, Uruguay. She is a professor at the Economic and Social History Program at the Social Sciences Faculty in the same university. Her main research fields are gender, labor market, wage inequality, and development. 